\title{
Reflections Upon Transitions: An Essay on Learning How to Teach after Practicing Law
}

\author{
C. Benjie Louis*
}

\begin{abstract}
Every academic year, new law school faculty enter legal academia. Many of these new teachers are practitioners with varying levels of legal practice experience. While the transition from practice to teaching is particular to each person, for clinical professors there are some specific challenges that transform our professional identity. Clinical professors wear many hats: teacher, lawyer, mentor, and scholar. Navigating those many hats and adjusting to various goals of teaching emerging attorneys is only a couple of challenges. Other challenges include changing the focus of our professional identity from career-centered, in its many facets, to student centered.

A core component of clinical legal education is the reflective process. A reflective lawyer is one who thoughtfully digests information and thinks about how an experience affects his or her professional growth. A reflective teacher does the same. This article shares some of my reflections on becoming a clinician and what I learned through experiences about becoming a more effective teacher.

In Part I, I reflect on my role as a supervisor of emergent attorneys and a goal facilitator for these same students who are exploring their educational and professional development. Part II includes lessons unique, I believe, to a clinician of color. Finally, Part III concludes with reflections on five core tools I have used that helped me in my transition; these tools, I believe, could be useful to new clinicians, especially those that have been practicing for a long time before teaching.
\end{abstract}

* C. Benjie Louis, Assistant Clinical Professor of Law, Albany Law School. I would like to thank my colleague, Prof. Melissa Breger, and my Research Assistant, Kyle Meredith, for their invaluable support and assistance in the creation of this essay.

Copyright (C) 2012 C. Benjie Louis, Esq. All rights reserved. 


\title{
Reflections upon Transitions: An Essay on Learning How to Teach after Practicing Law
}

\author{
"The only person who is educated is the one who has learned how to learn and \\ change." Carl Rogers
}

\section{Introduction}

Four and a half years ago, I began teaching at Albany Law School (Albany Law) after more than a decade of practicing law as a public interest attorney. Most of my time at Albany Law has been spent teaching a clinical course; I spent one year teaching non-clinical courses.

I did not know a great deal about the mechanics of teaching at the graduate level before I started, but I just knew I was extremely excited about the opportunity. Having supervised summer law interns, I was confident that my transition would be seamless. While some aspects of teaching came naturally to me, others did not; moments, particularly during my first semester at Albany Law, created opportunities for personal growth.

A core component of clinical legal education is the reflective process. ${ }^{1}$ A reflective lawyer is one who absorbs information and thinks about how an experience affects his or her professional growth. A reflective teacher does the same. This article shares some of my reflections on becoming a clinician after many years away from academic life and includes challenges that are universal to teachers.

My preparation for teaching my first semester at Albany Law was brief and I, like all new teachers, learned a great deal on the job during that first semester. There is wonderful scholarship that introduces new clinicians to the historical context of clinical legal education and to the hallmarks of clinical pedagogy, such as case rounds, client-centered representation, and the stages of supervision ${ }^{2}$; this article focuses on the essential ingredient that makes teaching so fascinating and challenging: the students. I ascertained that my professional persona, which was principally selfcentered and client-centered, had to modify to being student-centered.

My interactions with students, especially during the first semester of teaching, give a snapshot of the typical challenges of a new clinician. I had to adjust my desire to control cases ${ }^{3}$ and, thus, figure out what my role as a supervisor entailed. ${ }^{4}$ Appreciating the nuances of fostering student autonomy was another important matter to be learned. In addition, my role as a clinician of color impacted my experience as well.

In Part I, I reflect on my role as a supervisor of emergent attorneys and a goal facilitator for these same students who are cultivating their educational and professional development. Part II includes lessons unique, I believe, to a clinician of color. Finally, in Part III, I conclude with reflections on

1 William P. Quigley, Introduction to Clinical Teaching for the New Clinical Law Professor: A View from the First Floor, 28 Akron L. Rev. 463, 481-82 (1995).

2 See generally Justine A. Dunlap \& Peter A. Joy, Reflection-in-Action: Designing New Clinical Teacher Training By Using Lessons Learned From New Clinicians, 11 Clinical L. Rev. 49 (2004); William P. Quigley, Introduction to Clinical Teaching for the New Clinical Law Professor: A View from the First Floor, 28 Akron L. Rev. 463 (1995).

3 Dunlap \& Joy, supra note 2, at 67.

4 David F. Chavkin, Am I My Client's Lawyer?: Role Definition and the Clinical Supervisor, 51 SMU L. Rev. 1507 (1998). 
five core tools I have used that helped me in my transition ( and which I still use); tools that could assist new clinicians, especially those that have been in practice for many years prior to teaching.

\section{PART I}

\section{A. Reflection on the beginning}

In January 2007, I took a sabbatical from my job as a housing attorney in a legal services office in order to teach a clinical course at Albany Law called "Introduction to Litigation"; the subject matter of the course was unemployment insurance benefits. Albany Law is a private, independent law school in New York's capital. ${ }^{5}$ I had been a legal services attorney for many years before I started to teach and my entry coincided with the genesis of major changes to legal education where criticisms on the delivery of legal education were taking root from different factions. ${ }^{6}$

I was far removed from my own law school experience and my familiarity with law students prior to teaching was limited to interaction with summer interns. I remembered participating in a clinic in law school but I could no longer fully appreciate what it was like to be a student. What was foremost in my mind during those couple of weeks in early January were two things: what would the students be like and what will I say during the first class?

So what is my most striking memory of my first class? A story that I have told to almost every subsequent clinic class since I started teaching (7 classes altogether) is when I asked a returning student to share thoughts on the student experience of the litigation clinic from the previous fall semester. She stated that "all of the clients lied". There was laughter in the room and, after I took my jaw off the floor, the wheels spinning in my head were calculating how long it would take me to pack my bags and return to my old job. I asked her what she meant and she elaborated that when talking to her fellow student interns about their experience at administrative hearings, the testimony of the clients differed when they were under oath during those hearings from the stories they told the student interns. I was so taken aback that I really did not know how to respond and I mumbled something about not all clients lie.

After class, I wondered about their cynicism at such an embryonic stage of their professional development. My experience with clients was so different. Sure, some do lie, but the amount of facts and information culled from a client and understanding those facts and what facts really changed could be a complex process at times; consistency in stories is critical to a client's credibility. At that moment I figured out that the initial impact of a live client experience had the power to shape the students' view of the attorney/client relationship in a negative way. I wondered how many students had experience in law firms and how many had conversations with practicing attorneys about fact gathering that occurs during the attorney/client relationship.

Later that week, the student told me that she felt bad about her statement, but I appreciated her honesty. Honesty is important, especially in the clinical setting where there is so much close

5 About Albany Law School, http://www.albanylaw.edu/sub.php?navigation_id=1 (last visited Aug. 4, 2011).

6 See generally Jill Schachner Chanen, Re-engineering the J.D.: Schools Across the Country are Teaching Less about the Law and More about Lawyering, 93 A.B.A. J. 42 (July 2007); Roy Stuckey et al., Best Practices for Legal Education: A Vision and a Road Map (Clinical Legal Education Association 2007); William M. Sullivan, Anne Colby, Judith Welch Wegner, Lloyd Bond \& Lee S. Shulman, Educating Lawyers: Preparation for the Profession of Law (Jossey-Bass 2007). 
interaction between students and teachers. Her statement in class taught me a few lessons. One, my mindset that first semester was that, as a teacher, I needed to have an answer or sage comment for everything said in class. Room for the unpredictable was not something that I thought about in the beginning. Having practiced and gained some expertise and confidence in my ability to practice, I was in a place in my professional life where there was little variability. So, very soon into my legal teaching career, I was snapped out of that complacency. Two, the live client experiences, and unpleasant ones at that, would exist and I needed to think about different scenarios that can shape the student experience in a potent way. Third, if you plan to call on a student about sharing a specific topic for a specific purpose, it is sometimes beneficial to find out what the student is going to say ahead of time. This last lesson is not to suggest that you script your class; on the contrary, some topics, like client credibility, are ripe for exploration and discussion. But treading carefully with the unpredictable is an important part of the transition.

On a more pedantic note, after the class, someone asked me a practical question that did not occur to me as I was preparing for my first class: where did the money to pay for unemployment benefits come from? I answered the question, but started second-guessing myself about the amount of material I covered. How much to cover in one class (or one semester) and in what amount of detail is a universal struggle for any teacher. Asking yourself what the students should absolutely know by the time they leave your class that day is a way to overcome this issue; this was a question I would ask myself when I would prepare for court appearances. The idea behind this method is akin to one of the components of backward design where designing with clarity about what you want the student to learn before teaching it is critical. ${ }^{7}$ I did not know the theory of backward design when I started teaching; however, I, and many professors, employ it without necessarily knowing its details.

Another memory of that class is that I talked a lot. The Socratic Method ${ }^{8}$ is the predominant model in law school, depending on class size. ${ }^{9}$ However, creating a classroom where there is active student engagement is the aspirational clinic seminar model. ${ }^{10} \mathrm{I}$ was unaware of this when I started because I was focused so much on what I needed to tell the students that I had very little time to absorb andragological methodology prior to commencement of the first semester. Having taught now for four and a half years, and having read about active learning and student engagement, scaling back on lectures has been a conscious goal. I think it would be wise to cutback even more

7 "One starts with the end-the desired results (goals or standards)-and then derives the curriculum from the evidence of learning (performances) called for by the standard and the teaching needed to equip students to perform." Grant Wiggins \& Jay McTighe, Understanding By Design 8 (Assoc. for Supervision and Curriculum Development 1998).

8 "Socratic Method. A technique of philosophical discussion - and of law-school instruction - by which the questioner (a law professor) questions one or more followers (the law students), building on each answer with another question, esp. an analogy incorporating the answer... Most law professors who employ this method call on students randomly, an approach designed to teach students to think quickly, without stage fright." Black's Law Dictionary 662 (3d pocket ed. 2006).

9 William M. Sullivan, Anne Colby, Judith Welch Wegner, Lloyd Bond \& Lee S. Shulman, Educating Lawyers: Preparation for the Profession of Law 48-50 (Jossey-Bass 2007).

10 Stuckey et al., supra note 6, at 196-97 (where the authors list the variety of activities that a clinical seminar can undertake, most of which, like "group case planning exercises" or simulations, require active student engagement to succeed). 
and use a more problem-solving approach. ${ }^{11}$ A clinical seminar is a great place to have students talking in a meaningful way.

So how do you seek to engage students during the classroom component of a clinic? What I have done is incorporate questions into my teaching outline, ask students during class if they agree or disagree with a statement that has been made, and I try not to interrupt a dialogue between me and a student or two students until an objective is reached. Also, do not be afraid of the awkward silence, ${ }^{12}$ what I like to call the crickets singing in the night, in a classroom. There is a level of comfort that a student must feel in speaking up in class and eventually either someone will say something, or you can use a follow-up question to stir discussion. Anticipate misunderstandings ${ }^{13}$ and questions that your material does not cover. This is easier said than done in some instances because some of the most interesting issues arise organically.

\section{B. Reflection on Supervision}

Frequent supervisory meetings with students are a part of the clinical teaching experience. ${ }^{14}$ Prior to the first official supervisory meeting, at the beginning of the semester at Albany Law, students fill out an Educational Planning form which asks a series of questions about, among other things, the student's most enjoyable law school class, reasons for enrolling in the clinic, and what special skills the individual brings to the clinical experience. The next step is to meet with the student to discuss the content of the form. So, the form gives the student an opportunity to think about goals and gives the teacher insight into student goals and expectations for the semester.

In my transition during the first semester, having the Educational Planning Form proved to be a great launching pad into forming supervisory objectives and progressively developing my relationship with the students. The questions not only allowed me to start a conversation but also crystallized key targets of each student's expectations and the form is student-centered.

A valuable insight that I got from a colleague prior to starting to work was about the different prototypes of students that he had encountered during his years of teaching. I have named these prototypes as the following: the overconfident, the under confident, the workaholic, the adequate, the well rounded, and the unmotivated student. ${ }^{15}$ I could not discern upon the first meeting which prototype a student conformed to, but I kept it in mind as I talked to each of them. Which category a student falls into takes me, at most, until mid-semester to decipher. Their characteristics are as follows: the over-confident student believes, without a strong frame of reference, that (s) he knows the answers right away. The under confident student is one who is unsure about his or her decision-making and is constantly looking for answers from the teacher. The workaholic

11 The Carnegie Foundation's report on educating lawyers provides parallels of the problem-based method utilized with success in business and medical schools, saying that the technique, "in its wanderings... has enriched many other forms of professional preparation. Welcoming it back with its various enhancements would be to reclaim a legacy while acquiring new resources for legal education's own renewal." Sullivan et al., supra note 9, at 199-200.

12 Laurie Shanks, Whose Story Is It Anyway? - Guiding Students to Client-Centered Interviewing Through Storytelling, 14 Clinical L. Rev. 509, 522-23 (2008) (highlighting the "beachballing" technique, where the role of a professor's questioning is to "[lob] a beach ball into a group," placing the onus on the students to "keep the ball in the air.").

13 Wiggins \& McTighe, supra note 7.

14 Dunlap \& Joy, supra note 2, at 67, 90-91; William P. Quigley, Introduction to Clinical Teaching for the New Clinical Law Professor: A View from the First Floor, 28 Akron L. Rev. 463, 478-481 (1995).

15 Dunlap \& Joy, supra note 2, at 90-93. 
is the type of student that does clinic work to the detriment of other studies, thereby exposing a lack of work-life balance, another clinical teaching hallmark. ${ }^{16}$ The "adequate" student does the necessary work, but just scratches the surface on the intricacies of practice and is not particularly reflective. The well-rounded student is one who considers all components of the clinical learning experience. The unmotivated student is one that needs continual prompting in completing tasks and being reflective. ${ }^{17}$

These descriptions are not meant to be pejorative since; in fact, a good clinical experience meets these students where they are and facilitates their journey, hopefully, into a self-aware, reflective, and ethical practitioner. ${ }^{18}$ I give these descriptions to help the new teacher attune to the different personality types. As practicing law is a social profession, teaching law is a social profession multiplied tenfold.

My expectation in supervisory meetings is that the student is prepared to convey fact developments in a case or their research and those they have thought of, or struggled with, next steps in their preparation. I found that asking the student many questions and then having the student wrap up our conversation with a conclusion is sometimes helpful. It is an extension of the common clinical pedagogical technique of asking "what do you think." ${ }^{19}$ For example "what is your legal authority for making this argument or reaching that conclusion?" "What is your frame of reference for that comment?" "What would you do if this happened to you? The more questions asked, the less likely my own viewpoint intrudes into their process of coming to a conclusion.

\section{Reflection on fostering student autonomy}

I was away at my first clinical conference, in New Orleans, Louisiana. The conference took place right after the last week of Albany Law School's spring semester. There were a few cases that were still pending at the end of the semester and one of the cases involved a client, I will call him John Doe, who was waiting for a hearing date. The student on the case stated that he wanted to continue representing the client even after the semester ended, something he was not obligated to do as per Albany Law clinic policy, so I allowed him to continue working on the file.

While in New Orleans, I checked my e-mail periodically. One day, the student handling Mr. Doe's case sent me an email documenting how he was having a hard time with his client. Doe had not been returning calls thereby hindering the student's preparation of the case. In the email, the student told me that he reached the conclusion that the lack of communication with this client was such that he felt we should withdraw from representing him.

My reaction was swift and decisive. The case was still in its preliminary stages so my immediate reaction was "no" and that is what I replied to the student. My decision was neither deliberative nor reflective; I just decided to handle this as I would have in practice which was to basically give the client "another chance" to get in touch with me. Rather than engage in a dialogue with the student, albeit via e-mail, to explore whether the student's recommendation was an action that was warranted, I substituted my judgment for that of the student. I did not consider his own deliberation or reflection until I had a face-to-face meeting with him when I returned from the

16 Id. at 92 .

17 Id. at 90-93.

18 Quigley, supra note 1, at 489.

19 Quigley supra note 1 , at 482-83. 
conference. I realized, in hindsight, that by this juncture in the semester, the student had worked in the clinic for four months, had developed a good understanding of unemployment law, had the capacity to exercise judgment on the struggles on communication within this attorney/client relationship and was really in the best position to make a recommendation of withdrawal from representation. The decision-making process is part of being a lawyer and my quick, substituted judgment did not allow the student the opportunity to experience this essential part of lawyering.

What I learned from this experience is the foremost issue, in my opinion, that must be grappled with for a new clinical law teacher - when and how to let go of control over a case. ${ }^{20}$ This decision encompasses two clinical theories: directive versus non-directive, ${ }^{21}$ as well as the role of a supervisor in client decision-making. ${ }^{22}$ This is a recurring issue that is written about extensively and discussed at clinical conferences. I overheard a colleague say once that in teaching a clinic the "clients" were our students and the students had clients. This was a hard lesson to learn early on in my transition because I thought of myself as a lawyer first and, at that point, I could not wrap my mind on the idea that I was a "professor". The struggle between being directive and non-directive varies per student. ${ }^{23}$ In this anecdote, the student had represented two other individuals and he had a good grasp of unemployment insurance law. Yet, I was eager to seize control of Doe's case without much thought because I was quick to assume, without reflection, that the student was not making a good choice and I, with experience under my belt, could "fix" the client with a reality check. It turned out that the student's judgment of Mr. Doe was accurate and I ended up having the same communication problems with Mr. Doe once I officially took over the case when the student started a summer job.

So the lesson that I learned here was that the key to giving up control of a case was in reserving judgment on a decision until I let a student present a recommendation, and then probe the steps by which the student reached a conclusion. Probing such steps could take one supervisory meeting, or it could take multiple meetings. A student's decision could be simple or complex. Asking the question "why did you reach that conclusion" is only the first step. But, autonomy and exercising professional judgment are aspects of professional development that are essential to any lawyer's progress. The opportunity to do that as a law student should be cultivated by a teacher. So, the nuances of fostering student autonomy include giving the student the time and space to reach a conclusion, asking the student his or her decision-making process, and respecting a student's thoughtful determination.

The example I just gave involved a very serious decision. Also important, but more mundane, is decision-making on what could be perceived as minor, administrative tasks. I assigned a case to a student that was transferred from one semester to another. The client had been retained and during the course of a month, he was hard to reach via telephone. The client had been waiting for

20 Dunlap \& Joy, supra note 2, at 64.

21 "Non-directive supervision may be viewed as the manifestation of the Socratic method within clinical teaching. The questions that the teacher asks the student - guiding the student to explore issues, angles, facts, and theories the student may have left unconsidered and untested - is the measure of directiveness. On the more directive end of the scale, the teacher asks fewer questions and gives more instructions. At the opposite end, the teacher gives virtually no instruction but rather asks the students questions such as “what do you think?” Dunlap \& Joy, supra note 2 , at 84 .

22 See generally David F. Chavkin, Am I My Client's Lawyer?: Role Definition and the Clinical Supervisor, 51 SMU L. Rev. 1507 (1998).

23 Dunlap \& Joy, supra note 2, at 85. 
an administrative hearing so the new student was understandably anxious to speak to him.

I advised the student that we should send a letter to the client advising him that his case would be closed if he did not contact us. A few days later, the client called during a time outside of the assigned student's clinic hours. I spoke to him and he asked me to not close his case and also advised me that he received a hearing notice. The hearing was scheduled within two business days of our conversation, so I told him I would speak to the student about reopening his case and requesting an adjournment.

When I saw the student again, we discussed the situation and whether to continue representation; I had decided that we would but wanted a dialogue with the student about the impact of the lack of communication. I directed him to send a letter to the hearing office, via fax and regular mail, requesting an adjournment. After approving the letter, the student was left to follow up with getting it in the mail and faxing it.

The next day, which happened to be a Friday, the student did not have office hours, so I checked the client file. The hearing was on Monday, so I wanted to call the client to confirm the fax had been sent. I saw the letter I had approved, but no fax transmittal sheet. I checked the copy machine area, but no transmittal sheet was there either. I asked the paralegal for my clinic to confirm with the hearing office that the fax had been received (it was).

When I saw the student the following Monday, I asked about the whereabouts of the transmittal sheet. He said that in his haste, he stuffed the transmittal in his knapsack and left the clinic. Nothing adverse happened to the client's case, but that missing piece of paper caused me momentary panic. I talked to the student about how documentation is so important, especially in litigation, and it would have taken a minute to put the sheet in its proper place.

This incident highlighted for me that in addition to the clinic offering an environment where theory and practice are bridged; it also offers an example of working in a law office. Autonomy does not only include the ability to make decisions on a client's case; it includes the ability to function in a professional setting. There have been calls to make students more "practice ready" by the time they graduate from law school. ${ }^{24}$ What does practice ready mean? I posit that it not only includes the ability to see a case or a client holistically, but it also includes the ability to function within an office with its myriad responsibilities.

Following the administrative tasks can be bothersome and cumbersome. Filling out time records, making multiple photocopies of documents, and properly picking up a call that is on hold are a few examples of tasks that lawyers must do, especially if administrative support is scarce. I remember the tedium of proofreading my letters and making copies of pleadings. Taking care of these unexciting tasks can lead to awareness of the more serious things such as, re-reading an ethical rule on confidentiality or remembering to call a client back at a precise time when the client is available.

By reinforcing the fact that clinical work, even the uninteresting, mirrors real world work expectations, and having real consequences for failing to follow work rules, students can at least

24 The American Bar Association Section of Legal Education and Admissions to the Bar's 1992 "MacCrate Report" is perhaps the most notable call for increasing the practical aspects of modern legal education. Legal Education and Professional Development - An Educational Continuum, Report of the Task Force on Law Schools and the Profession: Narrowing the Gap, July 1992. 
see that part of being practice ready is adhering to office rules. I learned that teachable moments are also contained in routine office procedures. By keeping expectations high of all aspects of the clinic, students get a better picture of expectations that would be made of them in the "real" world.

\section{Reflection on being a goal facilitator}

Teaching in the clinic is a constant source of activity. Between supervising cases, preparing for seminar lectures, meetings within and outside the clinic, supporting school events, and supporting the work of the institution, finding the balance has not been easy for me, a sentiment shared by many clinicians of varying experience levels. ${ }^{25}$

However, being a clinical professor gives me the opportunity to interact with students on a cognitive and social level that is unique in the clinical environment. Most law school clinics have an 8 to 1 student/teacher ratio. ${ }^{26}$ This is true of the clinics at Albany Law and the student clinic office hours vary from 10 to 14 hours per week. ${ }^{27}$ In addition to the seminar component of the clinical course, you can expect to spend a lot of time with your students. Naturally, more personal information is being exchanged because an organic component to working in a clinic is collegiality. More than mentoring, students and clinical professors are at a level where the actual practice of law, something that the student may be doing for a life time, is dissected, probed and examined. In practice, there is always time for socializing and the line between what is appropriate socialization with students and what is not is one that you should discuss with your colleagues.

Because of the close nature of teacher/students in clinics, supervisory meetings and discussions on cases allow for many hours with a clinic professor. ${ }^{28}$ As students became more comfortable with me, it was not unusual for me to have conversations with them about more than their casework. Some have been initiated by students, others by me. Conversations about their career goals, learning styles, and reputations have been recurring topics with my students. Since many clinic students are second years, the exploration of what to concentrate on and where to focus a job search are typical issues.

Students, understandably, are focused on finding a job as soon as they graduate, especially in this bleak job market. ${ }^{29}$ Therefore, their stress level can be more intense. However, I think it is also wise to encourage students to think beyond the first job, examine their talents and be open to exploring what their law degree can be used for beside practicing law, especially with the glut of law students that are graduating compared to the number of legal jobs that are available. Over the years, I have listened to the anxiety of students who wonder whether going to law school was a mistake. Some of the procedures used in client interviewing and negotiations, such as identifying

25 Dunlap \& Joy, supra note 2, at 60.

26 "The most frequent student-teacher ratio for the classroom component of in-house clinics is 8 to 1 ( $38.1 \%$ ), followed by 4 to $1(11.2 \%), 6$ to $1(9.3 \%), 5$ to $1(8.7 \%), 10$ to $1(7.9 \%)$, and 12 to $1(5.2 \%)$, with all other reporting ratios below 4\%." Center for the Study of Applied Legal Education, Report on the 2007-2008 Survey 15, available at http://www.csale.org/files/CSALE.07-08.Survey.Report.pdf.

27 Albany Law Clinic and Justice Center registration material on file with author.

28 Quigley, supra note 1, at 488.

29 William D. Henderson and Rachel M. Zahorsky, Paradigm Shift, 97 A.B.A. J. 40 (July 2011), available at http:// www.abajournal.com/magazine/article/paradigm_shift/. 
goals and active listening, are useful tools in developing the teacher/student relationship. ${ }^{30}$ Because of time constraints, it is not easy to take the time to listen to students about non-clinic related subject matter, but I think it is important to do so. Clinical professors have access to students that carries significant capital. With the amalgam of factors that are weighing on a student's time, taking the time to listen to the student allows for insight into the student's professional development.

My clinic has a litigation focus and I am able to decipher, at least by the end of the semester, who is good litigator material and who would struggle within that setting. I can also identify those who will work well in an office setting and those who should be a solo practitioner. Having a sense at least of the solid skill set they would need and how to translate that into a successful presentation was essential.

Our charge includes helping students to think beyond their clinical experience, as well, to gravitate towards classes that will help them achieve their goals. I have incorporated questions about career goals in some of my supervisory meetings and I try to address it in some form during the end of semester meeting. All future litigators are advised to take negotiations and mediation. For students that are afraid of public speaking, I suggest that they take small seminars to build their confidence in talking in front of a group.

I say during my first class of the semester that a semester in the clinic is a snapshot of what kind of lawyer a student will be. Sometimes, however, the student doesn't know fully what s/ he wants once the reality of practicing law sets in. It is not glamorous and it is hard work. As we encourage students to look at a client's case holistically, we should do the same with our students. Clinicians could be the first exposure to a practicing attorney that a law student has, therefore, an innate knowledge of the rigors and benefits of real life practice can only enhance a student's comprehension.

\section{PART II. Reflections on being a clinician of color}

I am the only clinician of color at Albany Law and shouldering that status has been a learning process for me, one that really started towards the end of my first semester. At that time, I was casually approached by two students of color who were not in my clinic. We spoke for a few minutes about the stresses of the end of the semester; then the conversation turned to comments about the discomfort they felt in expressing themselves in class. The conversation was in the clinic's kitchen, a public but distant part of the clinic. I listened to them and while we were talking, someone, who happened to be white, came to the kitchen. I, and the two students, immediately stopped talking and just looked at each other. It was a familiar, and universal, halt of conversation that is had when you do not want the new person entering the room to know about the content of a conversation. I realized at that moment that I did not consider that my presence in the clinic was positive for these particular students. I do not think they could have the same conversation with a white professor and I told them to come and speak to me again.

This conversation illustrates the most personal aspect of my teaching transition which is the impact that students of color have had on me. I am Haitian-American and grew up most of my life in New York City. I am acutely aware of the feelings of isolation and discomfort that can be exacerbated when entering a new environment. It is the mission of law schools, including Albany

30 See generally Harriet N. Katz, Stories and Students: Mentoring Professional Development, 60 J. Legal Educ. 675 (2011). 
Law, to increase and encourage diversity at their institutions. ${ }^{31}$ Much has been written about the importance of having racial diversity in law schools ${ }^{32}$ as well as law school clinics. ${ }^{33}$ When I practiced law in Chemung and Dutchess counties in New York, there were very few lawyers of color. I have had a few memorable and disturbing interactions with clients that were directly related to my race, but for the most part, I was used to being the minority in many situations.

Over the years, other students of color, even those who were not in my clinic class, have talked to me about their social struggles at Albany Law; mainly identified as fitting into the culture of the school and the law where you do not have a lot in common with the people around you, feelings that are endemic in the academic setting for students of color. ${ }^{34} \mathrm{I}$ have heard about feelings of exclusion and perceiving that their voice was not heard, not sought after or respected. I did not have the benefit of having someone in my family that was a lawyer, so I really did not know what to expect from law school. My experience is not unusual for people of color, especially AfricanAmericans and Latinos. ${ }^{35}$

Comments that are common among minority groups; feeling uneasy around white students, a lack of outreach made by the "majority" at the school, feeling uncomfortable with verbal expression because of limited English proficiency, unfamiliarity with or indifference to the social expectations of practicing law (e.g. presence in business related social events), and feeling the burden of educating people about the complexity of the minority experience in America are recurring themes in my conversations. These types of topics are not unfamiliar to me. My experience that first semester made me aware that I should be an outlet for students of color and that race, in spite of the assertion by some that we live in a "post-racial" society, ${ }^{36}$ is still a palpable topic in the minds of some students.

For a student of color who is entering a workplace or a profession with unfamiliar rules, the clinical experience affords an extra dimension when they can open up to a teacher who has faced similar struggles. For those who have limited English proficiency, navigation of the dominant language is an extra weight attached to learning social norms. My background, especially my

31 For the purposes of this article, the use of the term "diversity" will be relegated to people of color.

32 See generally Kevin R. Johnson, The Importance of Student and Faculty Diversity at Law Schools: One Dean's Perspective (U.C. Davis Legal Studies Research Paper Series No. 242, 2011), available at http://ssrn.com/ abstract $=1769285$.

33 See generally Jon C. Dubin, Faculty Diversity as a Clinical Legal Education Imperative, 51 Hastings L.J. 445 (2000).

34 Pamela Edwards, The Culture of Success: Improving the Academic Success Opportunities for Multicultural Students in Law School, 31 New Eng. L. Rev. 739, $757-59$ (1997); Paula Lustbader, Teach in Context: Responding to Diverse Student Voices Helps All Students Learn, 48 J. Legal Educ. 402, 403-04 (1998).

35 According to the Law School Admission Council, of all students that entered law schools in Fall 2010, Black/ African-American and Latino/a students represented $7.2 \%$ and $6.1 \%$ of matriculants, respectively. Law School Admission Council, Matriculants by Ethnicity, http://www.lsac.org/LSACResources/Data/matricsby-ethnicity.asp (last visited Aug. 9, 2011). These numbers stand in stark contrast to the percentage of Blacks/African-Americans and Latinos/as present in the general population: $12.6 \%$ and $16.3 \%$, respectively, according to the 2010 Census. U.S. Census Bureau American FactFinder, Profile of General Population and Housing Characteristics: 2010, http:/factfinder2.census.gov/faces/tableservices/jsf/pages/productview. xhtml?pid=DEC_10_DP_DPDP1\&prodType=table (last visited August 8, 2011).

36 "Just as John F. Kennedy was only incidentally a Catholic, so is Obama only incidentally a black man. It is not just that he is post-racial; so is the nation he is generationally primed to lead." Richard Cohen, The Election That LBJ Won, Wash. Post, November 4, 2008, available at http:/www.washingtonpost.com/wp-dyn/content/ article/2008/11/03/AR2008110302609.html?hpid=opinionsbox1. 
immigrant upbringing, makes me sensitive to the concerns of students and I have come to be mindful of my availability to this population of students and providing them a safe place to express sensitive topics.

I have had informal conversations with students of color in my office about practicing law in a predominantly white profession. ${ }^{37}$ Giving them anecdotes of blatant and subtle racism that I have encountered with different factions of the legal world has offered them a taste of reality and validated their fears, to some extent. And, it has offered them a forum to vent their frustrations about racism's impact on their professional development.

Being very specific about why I am asking a question related to race is another lesson. The teaching of cultural competence is a hallmark of clinical legal education. The teaching of cultural competence has another dimension to the conversation because of my race. How or when to offer personal anecdotes is a delicate balance, in my experience.

The benefit to having faculty diversity in clinics is well documented. ${ }^{38}$ The lessons that I have learned are to make myself emotionally available to talking about race, be open to bringing up the topic of race, no matter what the color of the student, when I think the topic should be considered, and encourage students of color that the pursuit of a law degree will not only benefit them, but the legal profession as well.

\section{Part III- Reflection on practical aids}

As clinicians we spend a great deal of time tracking the progress of our students throughout the semester. We juggle assessment of their intellectual capacity, interpersonal skills, and ethical knowledge. While supervisory meetings give tangible opportunities to assess a student, I have found that other tools, such as rubrics, are very useful. The clinical community is generous about sharing information on rubrics and other assessment tools.

I did not have the benefit of attending a new clinicians conference before I started teaching. My first semester teaching was jam-packed with information that required much effort to absorb in a short period of time. Different people have different approaches to teaching, especially because of the nature of the subject matter of their clinic. ${ }^{39}$ Having the benefit of hindsight, I can reflect on tools that really helped my transition in being less self-focused and more student-focused. In reflecting on what practical tools have helped me in doing so, I relay five the five below that were critical tools in my transition to clinical teaching.

37 Among those students entering law school in Fall 2010, only about 26\% of those who responded were minorities. Law School Admission Council, Matriculants by Ethnicity, http:/www.lsac.org/LSACResources/Data/matricsby-ethnicity.asp (last visited Aug. 9, 2011). In practice, the picture is even bleaker. Among private law firms, only $6.16 \%$ of partners were minorities. National Association for Law Placement, A Closer Look at NALP Findings on Women and Minorities in Law Firms by Race and Ethnicity, http://www.nalp.org/jan2011wom_min (last visited Aug. 9, 2011). Only 15.4\% of federal judges are minorities. Pat K. Chew and Luke T. Kelley-Chew, The Missing Minority Judges, 14 J. Gender Race \& Just. 179, 179 (2010).

38 See generally Dubin, supra note 35.

39 Dunlap \& Joy, supra note 2, at 109 (survey results from the 2003 Conference participants show the variety of clinics available, from Criminal Defense and Prosecution to Elder Law to Immigration Law). 


\section{i. Agendas}

One of the greatest challenges, and part of fostering autonomy, is to have students take ownership of their cases. ${ }^{40}$ Taking ownership means investing the time, diligence, and intellectual discernment to be thoughtful about every step in a case. I remember agenda setting as an instrument that was suggested at the first new clinicians conference that I attended after my first semester teaching. In my supervisory meetings, I ask the student or student team to give me agenda items first. They do not need to give me something in writing, they just need to think about it first and then I jot down the item when they come in my office. I then add my own agenda items after theirs.

Giving the student the first opportunity to set the agenda is helpful, I think, to furthering ownership goals of a case. Often times, especially in the beginning of the semester, a student is grappling with what the next steps are in a case. I do remember that the start of my clinical experience as a student was overwhelming. Navigating what ownership means is a delicate balance for a novice because (s) he does not necessarily have the requisite experience to think two steps ahead in a case. In having an agenda and sticking to it, I find that I listen more than speak; I identify struggles more pointedly because the student can tell me what he or she is struggling with. This will allow you to use the time more efficiently and a consensus can be reached from the very beginning on what needs to be addressed before the meeting is over. Such structure may not be feasible if an emergency situation comes up in a case, but agenda setting is a valuable tool. I am thankful that allowing the student to set the agenda in the first instance minimizes my desire to control the case.

\section{ii. Case plans}

At Albany Law (and other clinics nationwide), several clinic professors have students use case plans for their cases: the template for the plan depends on the individual clinic director. ${ }^{41}$ When I started teaching, I used the case plan template of my predecessor and I found it to be the most useful device to track a student's thinking and struggles, particularly in the area of legal analysis. The format is similar to an appellate brief and it can go through multiple drafts throughout the semester. I give comments on each draft, give praise for some items, and point out when an issue has not been addressed.

The ability to follow the student's progress in a way that contains the essential components of a litigated case: the facts, legal issues, opponent's arguments, and the client's arguments, also helps me as a supervisor identify the needs of the case in a way that is balanced. Reading multiple drafts of a case plan has allowed me to give comments and suggestions in a time efficient manner and, I believe, it helps the student to see gaps in their formulation of the different aspects of building a case (factual theory, legal theory, and persuasive theory). Feedback from students about case plans has been mostly positive, including feedback that they will use them in practice.

iii. Going beyond "what do you think"?

I have had some blank stares when I ask this question. Being mindful of the inexperience of students is important. While the question is a critical tool, thinking about what comes after the answer from the student is equally useful. I think it is important to challenge students to express fully how they reach a conclusion. This means giving them space to think about a situation and

40 Id. at 62 .

41 The case plan that I use for my clinic appears at Appendix A. 
help them along the way to reach a legal argument. It may mean that you give the student a few hours or a few days to mull over the situation. Or, you could give the student hints about where they need to go to find an answer. Students need to develop professional judgment and ownership of a decision or conclusion is salient when they are encouraged to develop the steps to reach a conclusion.

\section{iv. Survey}

At the end of several semesters, I have administered an evaluation survey ${ }^{42}$ to my class that is different from the clinic's evaluation and Albany law's faculty evaluation. ${ }^{43}$ The idea for a survey came from a colleague with whom I co-taught a skills course. My clinic survey is very short and asks questions about what worked and did not work in the clinic that semester and I ask for reactions on something new that I have introduced. For example, I have used the movie "Rashomon" 44 three times as a companion to the lecture that I give on fact investigation; one semester I used the short story on which the movie is based, "In a Grove," by Ryunsuke Akutagawa. I use the film for several reasons. First, to encourage my students to listen to the same story, with conflicting testimony, in an effort to demonstrate that there are different "facts" they must investigate in their efforts to create a persuasive argument. Second, to impress upon students the fact that a lawyer cannot have tunnel vision when it comes to looking at a case holistically. Third, the film serves as a view into a different culture and generation, so it can serve as a springboard to discussing cultural competence, an important component of a lawyer's professional growth.

The first time I showed the film, there were positive comments about the movie being a nice change from regular class work. I also got some comments that it was hard to connect the movie to the aims of fact investigation. So, I refined the assignment ${ }^{45}$, with the help of a more experienced colleague, by taking the feedback from the students and modifying it to better fit the lecture on fact investigation. I have had a couple of comments that I need to select a more "current" film at least from the " $90 \mathrm{~s}$ " but my goal would be skewed, I believe, if the students recognized the actors.

Why have the survey completed anonymously? For the same reason that faculty evaluations are administered anonymously, in order to encourage honesty. In an office setting, complete honesty is not to a rule of thumb; you need only review blogs or books on proper office etiquette to know it is wise to keep certain comments to yourself.

Getting this extra feedback from students has given me better insight on what I needed to clarify for some assignments.

\section{v. Confidential notes}

Developing a system of keeping track of an individual student's progress and problems is especially useful. Unlike a traditional class where one exam or a mid-term measures a student's legal knowledge, a clinical professor can see dramatic changes on a weekly basis. Having a mechanism to remind me of milestones, issues, and observations of the student has helped me in providing

42 I got this idea from my colleague, Laurie Shanks.

43 Both evaluation forms on file with author.

44 Rashomon (Daiei Studios 1950). David Chavkin suggests this film, among others, in the teacher's manual for "Clinical Legal Education."

45 I was helped a great deal by my colleague, Nancy Maurer. 
feedback throughout the semester and especially at mid and end of semester meetings. Giving meaningful feedback is essential to the clinical experience. ${ }^{46}$ However, giving good feedback is a universal pursuit of teachers and one that is encouraged in the current push for law schools to create outcome and assessment tools. ${ }^{47}$

Either at the end of the day or the end of the week, I jot down notes about the performance of each student. ${ }^{48}$ The notes are basically in three categories-supervisory meetings, seminar, positive and negative anecdotes. I do not share these notes with anyone but I use them to refresh my memory when I meet with my students. Taking time to write notes to yourself throughout the semester on how each individual student is growing, or not, so that your feedback can not only be supplemented with concrete examples, but can also remind you of the noteworthy highlights of each student's progress.

\section{Conclusion}

The transition into teaching in the clinical setting has been a process filled with many highs and lows. The aspects that are familiar to practice- interviewing, formulating arguments, thinking about strategy- take on a new dimension when they are being cultivated in an emerging lawyer. Being student-focused is what teaching is all about; what I have talked about regarding relinquishing control, being a mentor, and being available to students is a balancing act that is part of being a clinical teacher. These aspects flow and change depending on the student and they continue as each semester brings the same and new challenges. While my aim in writing this article was to convey concrete examples and ideas for new clinical teachers, my hope is that it resonates with experienced ones, as well. There has been much talk about reforming legal education ${ }^{49}$ and I think that seasoned practitioners add to the richness of legal education in ways that complement the traditional law school curriculum. Seeing someone's professional growth, someone who will be a future colleague, is a tremendous privilege.

46 "The guidance and feedback that students receive in experiential education courses influences the quality of the experience more than any other component." Stuckey et al., supra note 6, at 175

47 Id. at 239-40.

48 A sample is attached as Appendix B. This is an example only. The names in this form have been made up, as have the notes attributed to these fictional students.

49 Karen Sloan, AALS Urges Delay in Debate Over Law School Accreditation Standards, The Nat'1 L. J., March 30, 2011, available at http:/www.law.com/jsp/nli/PubArticleNLJ.jsp?id=1202488584781\&slreturn=1\&hbxlogin=1 (highlighting the American Association of Law Schools' objections to several proposals being floated by the American Bar Association's Standards Review Committee, which is currently updating law school accreditation standards). 


\section{APPENDIX A}

\section{CASE PLAN TEMPLATE}

Client:

Date of File Origination:

Intern Responsible:

Supervising Attorney: Prof. C. Benjie Louis bloui@albanylaw.edu

Dates and pages of case plan updates and comments:

Case Plan Initiated:

Case Plan Updated

I. Parties in this action:

Name of Dwelling's owner:

Address:

Phone:

Contact:

II. Summary of Facts:

III. Factual Questions/Problems specifically to be addressed:

IV. Questions of Law specifically to be addressed:

(i.e., notice to vacate, eviction notice.) 
V. Statutes and regulations involved:

VI. Legal Position: (Prior legal decisions)

A. Lower Court Decisions

B. Appellate Court Decisions

C. Court of Appeal Decisions

VII. Owner's position:

A. Factual

B. Legal

VIII. Best Facts to support Owner's version of the issues:

ISSUE

BEST FACT

SOURCE

HOW TO GET FACT 
IX. Apply law relevant to specific issues (from 8 above):

X. Our Position

A. Factual

B. Legal

XI. Best facts to support our version of the issues:
ISSUE
BEST FACT
SOURCE
HOW TO GET FACT

XII. Apply law relevant to specific issues (from 11 above):

XIII. Notes for Negotiation/Oral Argument/Closing:

(i.e., summary of testimony, arguments) 


\section{APPENDIX B}

\section{INTRODUCTION TO LITIGATION CLINIC}

\section{Spring 2011}

Week One (1/10)

\section{Doe, John}

- Missed scheduling a meeting to discuss educational goals. I had to send two emails to remind him. Apologized for oversight.

-Meeting - Made very little eye contact. During meeting, he took notes and advised me that he struggles with writing. Stated contracts was his favorite class so he was able to follow the overview on landlord/tenant law during class very well. States he does not like public speaking.

\section{Moe, Molly}

- Meeting was very productive. She was thoughtful about her strengths and weaknesses. Both parents are lawyers. She was clear about her desire to be a litigator. Does not think that she will like writing reflections. She had to do so for Field placement and found them boring.

- Came to court appearance with me on Friday. Asked pointed questions about client's legal argument and got a good grasp of the two main issues in the case. She was able to relay the legal issues to me on the way back to school.

- on a journal and states she has time management problems.

\section{Jones, Jane}

- Disorganized at the meeting. She did not answer all of the questions on the educational planning form. Stated she hated law school so far and hopes clinic will give her motivation to continue. (2L) Feels at a disadvantage because she is first in her family to go to graduate school.

- Per AA, she was distracted during computer training.

- In class, she stated during introductions that she has had family members who were homeless and came to live with her and her mom. Seems open to sharing her feelings.

\section{Smith, Bob}

- Hard to read so far. He missed extra class this week but gave no explanation of why.

- EPF had thoughtful answers about his skills (strong writer, hates public speaking, legal research skills are efficient). He already knows he does not want to be a litigator. Thinks this clinic will take him out of comfort zone. Does not like idea of collaboration. 
Week Two (1/17)

\section{Doe, John}

- assigned a case from last semester. Seemed very uncomfortable in class when it was his turn to present his case during case review. The facts were not presented in chronological order (as I had advised). Talked to him about this and he said he forgot my suggestion. I suggested that we do a run-through of his case before the next class.

- he initiated a meeting with me before he called the client (proactive)

\section{Moe, Molly}

- assigned a case from last semester. Gave the facts in chronological order. She was following a written outline-good preparation.

- She made some suggestions to JD about research and offered to help him (collegial)

\section{Jones, Jane}

- Did not contribute to discussion forum on TWEN and her first timesheet was not detailed enough. Was late for class and did not participate. Appointment made for Monday to discuss this.

\section{Smith, Bob}

All assignments completed. I advised him that I would assign a case to him and Jane to work on together. I gave some suggestions on collaboration and lent him a book; told him to read the chapter on collaboration. I asked him to come to my office on Tuesday to discuss the reading.

Week Three (1/24)

\section{Doe, John}

- good reflection paper about his fear of messing up a client's case. Lots of typos even though I suggested spell check. He seemed more comfortable with me during supervisory meeting. More eye contact and more questions about next steps in the case. We looked over the paper together. He stated he is dyslexic but that will not stop him from improving. I suggested seeing the writing specialist in the main building.

\section{Moe, Molly}

- reflection was a recitation of what she did over the past two weeks. I made suggestions at end of paper on how to tie the information into a comment about her professional growth.

- We discussed conference call with client. She feels that the client was rude because he asked so many questions. We talked about her perception of "rude" and she realized he was anxious about 
a new person on his case.

- good comments in class about lack of access to lawyers in housing court

\section{Jones, Jane}

- honest reflection paper on her difficulty with school and life and how the clinic's law firm format will give her a dose of reality.

- During our meeting, she said that she was recovering from an illness and missed deadlines. She has job on the weekends so she is adjusting to a lot. We discussed her schedule, principles of professionalism and strategies.

- Told her she would work with Bob on a new case. She was relieved; states she is a good collaborator and Bob will help her stay on schedule. We discussed balancing work and school.

\section{Smith, Bob}

- well-written reflection on how he would have to make many adjustments because of the clinic. He hopes to get along with co-counsel.

- articulated good points from this week's reading in an organized manner during class.

- we discussed collaboration and he said he decided that dividing tasks will be best way for him to work. I urged him to talk to co-counsel first before making a decision on that. 
